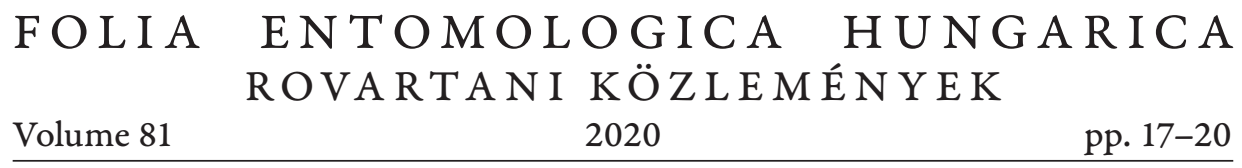

\title{
First record of Geocoris pallidipennis from Hungary (Hemiptera: Geocoridae)
}

\author{
Zoltán NAGY \\ H-7349 Szászvár, Gárdonyi Géza utca 2, Hungary.E-mail:nagyzee92@gmail.com
}

\begin{abstract}
Adult individuals of Geocoris pallidipennis (Costa, 1843) were observed and collected at the end of October 2019 and 2020 in Szászvár (Baranya county), Hungary. They were found in a drainage ditch in the village. This is the first Hungarian record of the species. With 2 figures.
\end{abstract}

Key words - distribution, Mecsek Mts, new record, true bugs

\section{INTRODUCTION}

Geocoris Fallén, 1814 is the largest genus of the lygaeoid family Geocoridae (Ко́воR et al. 2018). It contains about 120 species worldwide, with roughly 50 species known from the Palearctic region. Around 35 species occur in the Mediterranean part of Europe. Geocoris pallidipennis (Costa, 1843) is distributed in the Balkan Peninsula (РRотіć 2001, 2011), Turkey, Iran, Arabian Peninsula and in Central Asia (PÉRICART 1998). The hitherto known northernmost border of its distribution and the localities closest to our area are Trieste (Italy) and the Istrian Peninsula (Croatia), but a specimen labeled as "Bohemia" is known as well (Elöd Kondorosy, personal communication).

In the Hungarian fauna there were only six species from the genus (KoNDOROSY 1999, 2005). The new finding raises the number of species known to occur in Hungary to seven.

\section{GEOCORIS PALLIDIPENNIS IN HUNGARY}

The first adult individual of G. pallidipennis (Fig. 1) was observed on the side of a street drainage ditch in Szászvár (Baranya county, Hungary, N 46.2802 ${ }^{\circ}$, E $18.3714^{\circ}$ ), on 26th October 2019. The author photographed and collected it for further examination because of its unusual appearance. In March 2020 the taken picture was found again during imagery sorting. The collected specimen 
dried out in the meantime but it was in good condition and was identified as G. pallidipennis. Later on Elöd Kondorosy confirmed the identification. The specimen is in the author's collection.

In 2020 the author searched for other specimens throughout the year without success. On the 3rd and 4th October 2020 another six individuals were found in the same location. Three specimens are in the author's collection, while one specimen each is deposited in the Hungarian Natural History Museum (Budapest), in the Bakony Natural History Museum of the Hungarian Natural History Museum (Zirc) and in the Janus Pannonius Museum (Pécs).

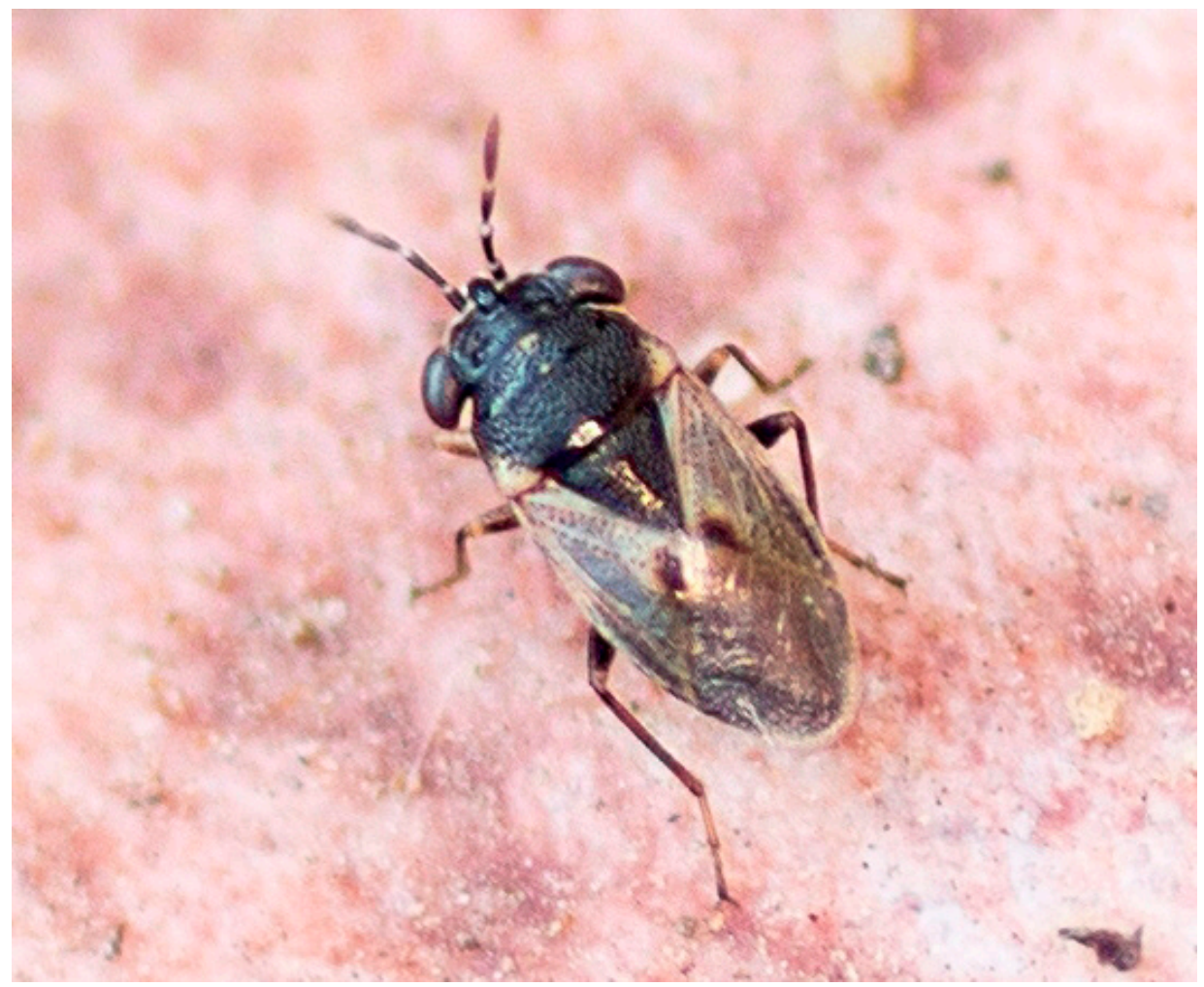

Fig. 1. The first individual of Geocoris pallidipennis Costa, 1843 from Szászvár, Baranya county, Hungary (photo by Zoltán Nagy) 


\section{DISCUSSION}

The origin of the first specimen is unknown. A theory suggested that it was due to transportation from a Mediterranean country, but the further alive bugs presume that a viable population should exist there. The area is home to a stable population of the common Geocoris ater (Fabricius, 1787), G. pallidipennis individuals were found and collected from the company of them. The appearance of the new species may not cause any ecological harm, it might fit in the fauna and be a part of the biological pest control as well. Further monitoring of its presence will be continued. The author made a coloured pencil illustration based on the first specimen (Fig. 2).

Proposed Hungarian name of G. pallidipennis: fakószárnyú nagyszemübodobács.

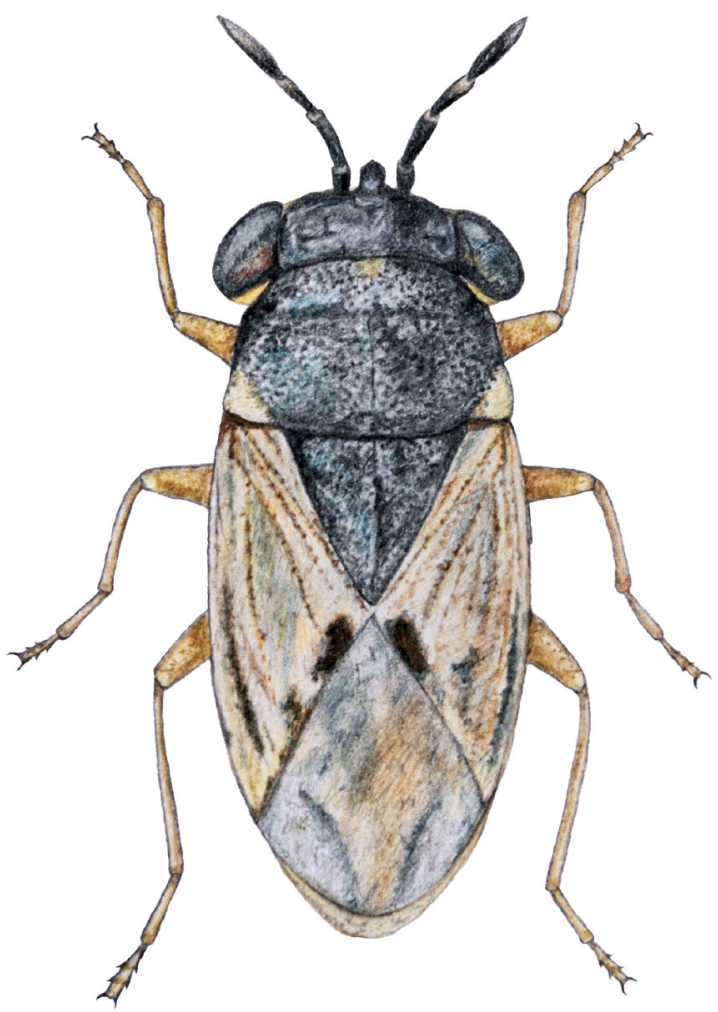

Fig. 2. Coloured pencil illustration, based on the first individual (drawing by Zoltán Nagy) 
Acknowledgements - I am grateful for the Kucska family (Szászvár) for their hospitality, which made possible to find the first population of Geocoris pallidipennis in Hungary. I would also like to thank the help given by Elöd Kondorosy (Szent István University, Georgikon Faculty, Keszthely), Beáta Horváthné Harmat (Bakony Natural History Museum of Hungarian Natural History Museum, Zirc) and Ottó Merkl (Hungarian Natural History Museum, Budapest).

\section{REFERENCES}

Kóbor P., Tóbiás I., Roca-Cusachs M. \& Kondorosy E. 2018: The subspecies concept in Geocorinae: an integrated taxonomic case study on Geocoris (Piocoris) erythrocephalus (Lepeletier \& Serville, 1825) (Hemiptera: Heteroptera: Geocoridae). - Zootaxa 4482(3): 541-550. https://doi.org/10.11646/zootaxa.4482.3.6

Kondorosy E. 1999: Checklist of the Hungarian bug fauna (Heteroptera). - Folia entomologica hungarica 60: 125-152.

Kondorosy E. 2005: New true bug species in the Hungarian fauna (Heteroptera). - Folia entomologica hungarica 66: 17-22.

PÉRICART J. 1998: Hémiptères Lygaeidae euro-méditerranéens. Volume 1. Faune de France 84A. Fédération Française des Sociétés de Sciences Naturelles, Paris, xx +468 pp.

Protić L. 2001: Catalogue of the Heteroptera fauna of Yugoslav countries. Part two. - Natural History Museum, Belgrade, $271 \mathrm{pp}$.

Protić L. 2011: Genus Geocoris Fallén (Heteroptera: Lygaeidae) in Serbia and adjacent regions. Acta entomologica serbica 16(1-2): 25-33. 